\title{
Terrorism, Counter-terrorism, and Critique: \\ Opportunities, Examples, and Implications
}

\author{
Lee Jarvis, University of East Anglia, ${ }^{i}$
}

\begin{abstract}
This article explores the parameters, value and limitations of different critical strategies for those dissatisfied with the contemporary politics of terror. It argues, first, that the prominent counter-terrorism paradigm - in which terrorism is approached as a ubiquitous and very specific security challenge meriting appropriately exceptional responses - is far more critiqued than we might anticipate. And, second, that such critiques - which can be found across political language, popular culture, everyday life, and beyond - employ distinct critical resources to serve varying ends. Reflecting on these, the article offers a new heuristic distinguishing five critical strategies which seek to: (i) repudiate; (ii) question; (iii) subvert; (iv) replace, or (v) deconstruct the prominent counter-terrorism paradigm. This typology, it argues, offers scope for optimism and strategic resources for those attracted to a critical terrorism studies project going forward.
\end{abstract}

Keywords: critical terrorism studies; critique; criticism; counter-terrorism; terrorism

\section{Introduction}

This article offers a revised and expanded version of an inaugural lecture delivered at the University of East Anglia on 20 November 2019. ${ }^{\text {ii }}$ In it, I reflect on the value and challenges of distinct critical strategies for those of us dissatisfied with prominent ways of thinking about and responding to terrorism. The argument I develop is twofold. First, the common, widespread approach to terrorism as a very specific yet ubiquitous security challenge meriting appropriately severe, even exceptional, responses is problematic. It is problematic, in the first instance, because it relies upon a specific set of unnecessarily limiting assumptions about the nature of terrorism. But it is problematic, too, because it directly facilitates the social, political and human harm witnessed within contemporary forms of counter-terrorism. The second stage of my argument is that this (counter-)terrorism paradigm - although prominent and readily recognisable - is actually far more contested than we might anticipate. From academic scholarship to film, videogames, elite rhetoric, everyday experiences, and beyond we can identify numerous instances in which this paradigm is, in various ways, critiqued. Reflecting on these critiques, I argue, offers conceptual and normative guidance for those seeking to critically analyse terrorism, security or related phenomena.

The article begins by setting out my approach to terrorism as an intrinsically social construction. A second section then explores important examples of critique from a range of political, cultural and everyday practices derived from some of the projects on which I have worked. In the article's third section, I build a new heuristic from these examples, distinguishing five strategies of critique. These are characterised as efforts to: (i) repudiate, (ii) question, (iii) subvert, (iv) replace, and (v) deconstruct the politics of - in this case - (counter-)terrorism. The article concludes, finally, by reflecting on the implications of this heuristic for future work within critical terrorism studies and beyond, arguing that the examples explored here offer more hope for progressive ways of thinking and responding to terrorism than we might often fear. This, I suggest, contributes to existing debate on the nature of the 'critical' in critical terrorism studies 
and related scholarship (e.g. Gunning 2007; Jackson 2009; Jarvis 2009a; McDonald 2009; Toros and Gunning 2009).

\section{Problematising terrorism}

In December 2014, a number of songs from an upcoming album by the popular singer Madonna were leaked online before the album's release. That leak, Madonna wrote in a social media post, constituted an act of "“artistic rape" and "a form of terrorism" (Michaels 2014); a position she clarified in a subsequent interview in which she described "living in a state of terror", whereby: "Obviously there is a person, or a group of people behind this that were essentially terrorising me. I don't want to sound alarming, but certainly that's how I felt" (Petridis 2014). Seven years earlier, in April 2007, a prominent Catholic Archbishop condemned abortion as 'terrorism with a human face', using the same speech to denounce gay marriage as evil (Pullella 2007). And, twenty years before that, then British Prime Minster Margaret Thatcher famously condemned the African National Congress (ANC) as 'a typical terrorist organisation' at a press conference in Vancouver (BBC 2013). She did so six years before Nelson Mandela shared the Nobel Peace Prize with President Frederik Willem de Klerk, "for their work for the peaceful termination of the apartheid regime, and for laying the foundations for a new democratic South Africa" (Nobel Media n.d.).

These examples are interesting, I think, for three reasons. In the first instance, they spotlight the power of the language of 'terrorism' to denounce actions, individuals, or organisations we seek to condemn. In this sense - at least - these examples are far from uncommon. It is a familiar (and often tiresome!) rhetorical strategy to demonise or delegitimise one's enemies using this word, which carries with it such pejorative connotations. In part, this is why very few people today describe themselves as 'terrorist' although interestingly this wasn't always the case (Carr 2011, 32-37). Second, the slightly unusual appropriation of this language in these examples - particularly in the first two instances - also highlights this label's contestability. All of the actions referred to could, of course, be thought of in quite different ways: for instance, as music piracy, or the termination of unwanted pregnancies, or political resistance. There is, in other words, nothing inevitable about the choice of this language in any of these cases. Third, if we consider the condemnation of the ANC in particular, we also get a glimpse here of the consequences that can befall individuals or groups to whom this label is applied. Denouncing one's enemies as 'terrorist' offers a very convenient way of refusing to engage politically with the demands or the actions of others. 'We don't negotiate with terrorists', governments often tell us, even though we know that they very frequently do (see Toros, 2008; Powell 2015).

These examples, then, encourage us to think about terrorism not as a self-evident 'thing' that exists out there in the world, awaiting our discovery or study. But rather as something which is produced, constructed, or made. They encourage us to think about terrorism, in other words, as something which is brought into being in the ideas, language, and practices of people: from popstars, to politicians, religious leaders, and beyond. Let me clarify, though, because this argument is often misunderstood. We know, of course, that bombs go off, that aircraft get flown into buildings, that people get beheaded, and so on. But, actions such as these - and indeed others - only sometimes get thought of or discussed as 'terrorist' (Jackson et al 2010: 3; Schmid 2013: 68). The deliberate bombing of civilians, for instance, might be understood as terrorism - as with Timonthy McVeigh's 1995 'Oklahoma City bombing', or in the 2013 Boston Marathon bombing. Alternatively, it might be referred to as a military operation, as in the firebombings of Japanese and European cities during the second world war. Mass shootings, similarly, are 
sometimes referred to as terrorism - as with the November 2015 attack in Paris that included the deaths of 90 people at the Bataclan Theatre. At others, though, such shootings are widely depicted as hate crimes - perhaps in Dylann Roof's 2015 attack at a church in Charleston, South Carolina.

The point, for now, is that it is the act of producing, constructing or labelling something 'terrorist' - be it a bombing or a hijacking - that transforms any particular bombing or hijacking into an act of terrorism (Jackson 2005; Hulsse and Spencer 2008; Jackson et al 2009; Jarvis 2009a; Jackson et al 2011). In our efforts to make sense of the world around us, we create the world. And our creations are neither inevitable, nor are they neutral. They involve choices and exclusions, such that understanding violence in one way involves refusing, forgetting, or failing to understand violence otherwise. And those choices and exclusions, of course, are deeply political (Jackson et al 2011: 112-114), raising important questions such as: how is it that specific events become understood - or not understood - as 'terrorist'?; who decides when the 'terrorism' label is used?; who benefits from the use of this label?; and, how do prominent accounts of terrorism impact upon social life and political institutions?

\section{A dominant terrorism discourse?}

Once we start asking questions like these it is fairly tempting, I think, to make an argument that there exists a dominant way of thinking about terrorism today. This understanding is one that we can find across political speeches, newspaper headlines, films, novels, television shows, and in many other places besides. To simplify, a little, we might identify three features of this terrorism discourse.

First, the term 'terrorism' today typically refers to a quite specific set of violences: violences which are conducted by non-state groups against civilians in order to communicate something to an external audience. Although there are important academic exceptions (Stohl and Lopez 1984, 1988; George 1991; Chomsky 2002; Blakeley 2007, 2009; Jackson 2008; Jackson et al 2010), the word is relatively rarely applied to the actions of states. The prominent Global Terrorism Database (GTD, n.d.), for instance, explicitly excludes state violences from its purview, as do many - although far from all - governmental and scholarly definitions of this term (see Jarvis and Lister 2014: 45-46; Shanahan 2010). The communicative aspect here - the view that terrorism involves the use of violence to send some sort of message to an external audience - is, I think, what makes terrorism appear so reprehensible. The instrumentalisation of terrorism's victims so they are merely a means to other ends embodies so cavalier an approach to human life and wellbeing that seems so far beyond that which is normal or good. It is not, therefore, difficult to see from where more simplistic, caricatured constructions of 'terrorists' as mentally ill (see Heath-Kelly and Strausz forthcoming), or religious zealots (see Gunning and Jackson 2011), or simply evil (Jackson 2005), might derive.

Second, terrorism is widely understood to be a ubiquitous threat, one from which we are never entirely free. Alert systems, for instance, remind us that the present risk of future attack is never zero: that we are always, as Zulaika and Douglass $(1996,3)$ put it, 'waiting for terror'. Preparedness exercises and warning posters, similarly, encourage us to anticipate and prepare for terrorist atrocities so we are ready when they do - inevitably - occur (Amoore and De Goede 2011). ${ }^{\text {iii }}$ We encounter this ubiquity, too, in the perpetual wariness that now surrounds terrorism: the extent to which jokes circulated on social media (Hughes and Walsh 2010) - or the act of carryin books relating to terrorism (Sabir 2011; Fitzgerald 2015) - or writing in unfamiliar 
languages, especially on transport (Guardian 2016) - and even children's schoolwork (Victor 2016) - may all now be understood as suspicious.

Out of our first two features, we might draw a third, if more debated, characteristic, such that terrorism is often seen as presenting something of an exceptional threat (Neal 2009; BakerBeall et al 2018): one that is radically different to other forms of violence that may befall us. This sense of exceptionalism runs through the more outlandish anxieties around terrorists employing weapons of mass destruction (see Mueller 2009; Jackson et al 2011), whether British Prime Minister Tony Blair's fear that 'the possibility of the two coming together - of terrorist groups in possession of WMD ... is now, in my judgement, a real and present danger' (cited in Jackson et al 2011: 127, or - indeed - prominent concerns around the cyber- capabilities of terrorist organisations today: "Sooner or later, terror groups will achieve cyber-sophistication. It's like nuclear proliferation, only far easier' (McConnell, cited in Jarvis et al 2016: 620). This sense of exceptionalism is present - if often implicit - too, in today's 'new terrorism' fears that contemporary terrorists possess a brutality surpassing even that of their earlier counter-parts (Burnett and Whyte 2005). As R. James Woolsey famously put it in 1994, "'today's terrorists don't want a seat at the table, they want to destroy the table and everyone sitting at it' (cited in Morgan 2004: 11). Combining these three, then, we encounter an understanding in which:

The implicit, if not explicit, definition of terrorism is that it is an exceptionally bad form of violence. It is either bad because it is perpetrated by illegitimate non-state actors, bad because it kills civilians, bad because it deliberately intends to kill civilians or because it is violence that intends to terrorise in order to coerce (Dexter 2012: 131).

If we put all of this together, we are left with a prominent understanding of terrorism as a very specific - perhaps exceptional - form of violence that is never very far away. This is important for two reasons (see Jarvis 2009a). First, conceptually, such an understanding risks artificially fixing the meaning of terrorism. Doing so not only implies that this - social, produced, or constructed - phenomenon has an identifiable meaning or essence. It also militates against alternative conceptions of terrorism that would make use of a broader understanding encompassing, for instance, state actions under this term. The second reason this is important, however, is that our conception of problems or threats tends to play a vital role in shaping our responses to those (constructed) problems or threats. As President Bush's comments on the post' $9 / 11$ ' use of military tribunals make clear, if we think about terrorism as an exceptional threat, we are likely to support equally exceptional forms of counter-terrorist violence in response: 'To set up the option to use a military tribunal in the time of war makes a lot of sense. We're fighting a war, Terry, against the most evil kinds of people. And I need to have that extraordinary option at my fingertips' (cited in Jarvis 2009b, 144-145).

Although space is limited here for any comprehensive excavation of the costs of contemporary counter-terrorism, it is arguable that the contemporary period has been characterised by an excessive, perhaps exceptional, approach to this threat. A 2017 report from the Watson Institute at Brown University (Crawford 2017), for instance, estimated the US federal costs of the post-9/11 wars at $\$ 5.6$ trillion: a figure increased to over $\$ 5.9$ trillion in a recent update (Crawford 2018b). But the costs of counter-terrorism in the contemporary period are not purely financial. The same team of researchers estimates a total of 480,000 war deaths and 21 million refugees or displaced persons in the same period (Crawford 2018a); while Iraq Body Count (n.d.) currently reports 288,000 violent deaths in Iraq alone since the 2003 invasion. Numerous critics - within and beyond critical terrorism studies - have highlighted enormous 
incursions on civil liberties and human rights in the contemporary fight against terrorism facilitated by new and increasingly expansive frameworks involving the construction of new criminal offences and expanded powers of arrest, detention and deportation (Jackson et al 2011: 222-248). Such developments, of course, are rarely experienced uniformly, and frequently exacerbate existing social, political or cultural imbalances. Hence the impact of these developments upon multicultural life, with many communities reporting feeling stigmatised, even threatened, by contemporary counter-terrorism initiatives such as the UK's Prevent Strategy (Pantazis and Pemberton 2009; Baker-Beall et al 2016).

\section{Critiquing this discourse}

This prominent way of conceptualising and responding to terrorism does not appear a promising start for a discussion of critical potentialities. In the following, I want therefore to address this directly by highlighting some of the ways in which this discourse has been critiqued. ${ }^{\text {iv }}$ My argument is that - if we look carefully - we can find numerous efforts to re-think what terrorism is, what threat it poses, and what should be done to counter this threat; efforts that stretch across a range of sites within social and political life. Such critiques, I suggest, tell us something important about what might be done for those of us unhappy with the way the politics of terror tends to play out.

\section{Parliamentary discourse}

A first, and perhaps surprising, source of critique can be found in the actions of those responsible for establishing counter-terrorism responses: politicians themselves. A productive opening example, I think, can be found if we look at one of the most widespread, and enduring, mechanisms for addressing this threat: the power of proscription (Jarvis and Legrand 2018). Proscription refers to the banning of specific, named organisations from a designated territory. Although surprisingly under-studied, the power is central to the counter-terrorism strategies of many states and international organisations, despite often important differences in the identification of, and consequences facing, designated organisations and their members. In the United Kingdom, for instance, there are currently 74 'international terrorist organisations' banned under the Terrorism Act 2000, with a further 14 organisations proscribed under previous legislation relating to the Northern Ireland conflict (Home Office 2017). Membership of, and various forms of support for, these groups is a criminal offence in the UK - as it is in other jurisdictions (compare Forcese and Roach 2018; Legrand 2018; McGarrity and Williams 2018; Walker 2018); the power having been used in a number of high profile convictions including of 'hate preacher' Anjem Choudhary in 2016 for inviting support for ISIS (Dodd 2016), and - more recently - of a couple for membership of the far-right group National Action (De Simone 2018).

When the British government attempts to add new organisations to this list of banned groups - which has happened periodically since this contemporary regime's introduction in 2000 - Parliament is required to meet and debate the Home Secretary's request. These debates are significant because they offer a productive point of entry into elite conceptions and constructions of national identity (Jarvis and Legrand 2016) and - indeed - the political process itself (Jarvis and Legrand 2017b). They are more interesting, for our purposes here, however, because politicians frequently use these debates as an opportunity to depart from - and, indeed, to critique - the dominant understanding of terrorism explored above (see Jarvis and Legrand 2017a). There are lots of instances across these debates in which the meaning of terrorism - and responses to terrorism - are called into question. As demonstrated in Figure 1, these include: (i) concerns with 
the political dimensions of the language of terrorism; (ii) fears that draconian responses to terrorism might be ineffective, even counter-productive; (iii) concerns that efforts to counter terrorism through mechanisms such as proscription might be disproportionate, so powerful is this contemporary 'moral panic' (Cohen 2011); and, (iv) worries about the distinctiveness of terrorism vis-à-vis other forms of violence, and the risk that this label obscures potentially significant realities.

Figure 1: Parliamentary Critique in Proscription Debates

\begin{tabular}{|l|l|}
\hline Concern & Example from UK Parliamentary Debate \\
\hline Who decides? & $\begin{array}{l}\text { 'many Kurdish organisations are accused of terrorism by the Turkish } \\
\text { government, and their members are imprisoned, when in fact they are } \\
\text { democratic organisations fighting for the rights of the Kurdish people' } \\
\text { - Weir, 2006 }\end{array}$ \\
\hline Effective? & $\begin{array}{l}\text { 'Banning and proscription do not necessarily work. What works is } \\
\text { political dialogue' } \\
\text { - Corbyn, 2011 }\end{array}$ \\
\hline Proportionate? & $\begin{array}{l}\text { 'It is very easy to be unjust in the context of a crisis, an emergency, or } \\
\text { terrorism' } \\
\text { - Hogg, 2002 }\end{array}$ \\
\hline Consistent? & $\begin{array}{l}\text { 'should we not tread very carefully before proscribing an organisation that } \\
\text { has less blood on its hands than a government with whom we still maintain } \\
\text { diplomatic relations?' } \\
\text { - Price, 2002 }\end{array}$ \\
\hline
\end{tabular}

As Figure 1 demonstrates, then, it is possible to identify important examples of critique even at the heart of the British political establishment - where we might expect this prominent terrorism discourse to be at its most robust and coherent.

A related - if more implicit - moment of critique is also identifiable in those tensions and contradictions that emerge in government discourse around security threats such as terrorism. Although not necessarily as intentional or as pointed as the parliamentary examples considered above, I am referring here to those ambiguities and inconsistencies that tend to emerge in efforts to pin down the meaning or threat posed by terrorist violence. Consider Figure 2, for instance, which sets out some of the very different ways in which the George W. Bush administration framed and justified their unfolding war on terror through reference to temporal trends and dynamics. In the figure, we can see three attempts to reflect on the historical importance of the 
9/11 attacks, all taken from spokespeople for the Bush administration and separated by a period of only six weeks (see Jarvis 2009b).

\section{Figure 2: Contradictions in Political Discoursev}

\begin{tabular}{|l|l|}
\hline $\begin{array}{l}\text { Conception of } \\
\text { time }\end{array}$ & Example \\
\hline Discontinuous & $\begin{array}{l}\text { 'September 11 was a day like no other we have ever experienced' } \\
\text { (Cheney, 18 October 2001) }\end{array}$ \\
\hline Linear & $\begin{array}{l}\text { 'in some ways the September 11 attacks do not reflect a brand new trend } \\
\text { as much as a quantitative increase in the terrorists' sophistication, } \\
\text { planning and willingness to cause large scale destruction and loss of life' } \\
\text { (Taylor, 25 September 2001) }\end{array}$ \\
\hline Timeless & $\begin{array}{l}\text { 'Today, our freedom is threatened once again. Like the fascists and } \\
\text { totalitarians before them, these terrorists ... try to impose their radical } \\
\text { views through threats and violence' (Bush, 6 November 2001) }\end{array}$ \\
\hline
\end{tabular}

In the first example, Vice President Cheney positions the 9/11 attacks as an utterly unique, unprecedented, event: a break with everything we had previously known or expected. Building upon his earlier suggestion that 'the world shifted in some respects' (Cheney, in Jarvis 2009b: 64), Cheney contributes here to the framing of those events as an historical dividing point ushering in a 'new normalcy' (Cheney, in Jarvis 2009b: 64). As then National Security Advisor Condoleezza Rice (cited in Jarvis 2009b: 64) had similarly argued on 9 October 2001:

September $11^{\text {th }}$ was one of those rare dates that forever divides history into distinct categories of before and after. Everyone will remember what he or she was doing on September $11^{\text {th }}$. It was a day when the dark and impossible became a horrific reality for our country and for the world. We commonly hear the refrain that everything changed on September $11^{\text {th }}$. In many ways that is true.

In the second example of Figure 2, however, $9 / 11$ is located in a very different sort of history: as a development or escalation of previous types of terrorist activity. Here, those attacks are again presented as instituting something new, but the novelty, here, is gradual, incremental; an amplification of existing trends. As Secretary of Defense Donald Rumsfeld (cited in Jarvis 2009b: 106-107) argued in a speech at Carlisle Barracks in Pennsvylvania five years later:

Though we think of September $11^{\text {th }}$ as the first day in the Global War on Terror, it wasn't the first day for the enemy. Extremists had declared war on free people decades ago. In 20 years terrorists attacked and killed Americans more than 20 times .... During those decades the West was ambivalent about how to counter extremist ideology and that type of agreession. As a result, terrorists became increasingly bolder.

In Figure 1's third example - taken from then President George W. Bush - we see yet another conception of $9 / 11$, in which those attacks are interpreted as neither radically nor quantitatively 
new, but instead as a reincarnation of the sort of 'mad global ambitions' encountered from fascist and other totalitarianisms of the twentieth century.

The differences between these understandings of $9 / 11$ - and the tensions or contradictions they highlight - are important, I think, because they encourage us, again, to be cautious about terrorism's objectivity. If an event as newsworthy and pored over as the $9 / 11$ attacks can be plausibly understood in these very different ways by the same group of people, at the same point in time, then perhaps 9/11 lacks any sort of clear meaning. Put otherwise, these differences these tensions or contradictions - might therefore offer us a further way in to unpicking or deconstructing the prominent understanding of terrorism with which we began, and the political nature of efforts to fix terrorism's meaning.

\section{Everyday life and vernacular constructions}

It makes sense, in many ways, to begin by looking at the activities of politicians when seeking examples of critique in relation to established ways of understanding and responding to terrorism. These are the actors most responsible for, and most visible in, countering this threat. As such, their interpretations of the world, its potentialities and dangers, carry significant weight. There are, however, limitations to stopping our analysis there, and failing to look beyond this. In the first instance, doing so offers us only a very partial picture of our social and cultural landscape: one that misses all of the other places in which the threat of terrorism is thought, spoken, or written about. In the second, failing to look beyond elite political discourse assumes that the reception of such discourse - for instance, amongst general publics - is either unimportant, or predictable.

For reasons outlined in greater depth elsewhere (Jarvis and Lister 2013b; 2017b; Jarvis 2018), both of these assumptions can be seen as problematic. Research I have undertaken with Michael Lister (Jarvis and Lister 2015, 2017a) - as well as the work of others (Jackson and Hall 2017; Stevens and Vaughan-Williams 2017) - indicates that conceptions and constructions of terrorism and counter-terrorism amongst 'ordinary' citizens - for want of a better phrase - are both more important and less predictable than we might expect. Speaking to citizens about such topics, I suggest, offers a really vital way of engaging with the richness of public opinion around security politics, providing insight into citizen experiences of social and political life more broadly. And, as demonstrated in Figure 3, this can shed real light on public concerns, anxieties and fears.

\section{Figure 3: Citizen concerns ${ }^{\text {vi }}$}

\begin{tabular}{|l|l|}
\hline $\begin{array}{l}\text { Impact of } \\
\text { counter- } \\
\text { terrorism on ... }\end{array}$ & Example \\
\hline Rights & $\begin{array}{l}\text { 'there are draconian measures that are coming in that no free country } \\
\text { should have, and they are coming in under the guise of terrorism; playing } \\
\text { to people's worst, most basic fears' } \\
\text { - Llanelli, white, female }\end{array}$ \\
\hline
\end{tabular}




\begin{tabular}{|l|l|}
\hline $\begin{array}{l}\text { Political } \\
\text { engagement }\end{array}$ & $\begin{array}{l}\text { 'I would love to change things ... but right now, currently, I would rather } \\
\text { keep my mouth shut. ... Because a lot of your phone calls, without you } \\
\text { knowing, is monitored by MI5 anyway' } \\
\text { - London, Asian, female }\end{array}$ \\
\hline Identity & $\begin{array}{l}\text { 'these kind of laws ... make people feel really suffocated and really } \\
\text { alienated, and that's why there's problems with community cohesion' } \\
\text { - Birmingham, Asian, female }\end{array}$ \\
\hline Civic duties & 'Why should you help a government that doesn't want to help you?' \\
- Swansea, black, female
\end{tabular}

Figure 3 contains examples from a series of UK-based focus groups exploring how different communities make sense of, imagine and experience British counter-terrorism policy (see Jarvis and Lister 2015). The research set out to explore the implications for this for citizenship and security, out of which emerged a richer understanding of public fears and anxieties in this area. As Figure 3 demonstrates, these included fears that contemporary developments in counterterrorism policy have, amongst other things: diminished the rights held by citizens by curtailing freedoms of expression and association; rendered political participation or engagement far more difficult - especially for members of particular 'suspect' communities - potentially leading to a withdrawal from political debate and action; reduced the extent to which certain populations feel British today, isolating and alienating specific communities; and, diminished the sense of duty individuals might feel either horizontally - to one's fellow citizens, or vertically - to the state.

Public expressions such as these matter, I think, because they provide additional examples of genuine political critique - highlighting very specific ways in which citizens believe citizenship has been or is being eroded by contemporary counter-terrorism practices. In differing ways, the examples in Figure 1 question terrorism's objectivity, severity, and meriting of draconian responses. Yet, while pursuing research of this sort clearly helps enrich our understanding of public apprehensions, it might be more valuable still in helping to create new forms of critique: allowing members of the public opportunities to speak truth to power they might not otherwise have had. Consider two examples:

Our challenge to government, if this thing is going to be released to them, I challenge them with all the things that I've said, and I really hope that they look into all of the root causes of problems' (from Jarvis and Lister 2017b)

We need to cast open the net and look beyond the caricature of Muslims as extremists ... This project offers a unique opportunity to approach a section of British Muslim society that has not yet been engaged in dialogue, the voice of British Muslim women.

The first of these examples is from a focus group participant in the project discussed above. In it, she uses her participation in that group as an opportunity to make an explicit challenge to government. What are you going to do - she seems to be saying - now that I have shared my 
experiences with you. The second is from a potential contributor to a distinct, and more recent project, on the relationship between British values and Islam. ${ }^{\text {vii }}$ In response to our call for people to make original films on the theme of 'British [Muslim] Values', this individual explains her interest in contributing to this research as an opportunity to foreground lives, experiences, and values that are too frequently marginalised within media or political debates. In each of these example, then, contribution to academic research projects is seen - by research subjects - as a way of influencing or impacting social or political dynamics; of generating, in other words, critical reflection.

\section{Terrorism and counter-terrorism in popular culture}

A third space in which we encounter regular and significant criticism of a dominant terrorism discourse - alongside the examples from political language and everyday experience considered above - is in popular culture. Terrorism and counter-terrorism feature widely, of course, in books, films, television shows, videogames and beyond, often - although not always reproducing and confirming the sense of exceptionality with which we began our discussion (see Croft 2006; Morgan 2009; Holland 2011; Jackson et al 2011: 50-71; Robinson 2015; Pears 2016). But there are important examples, too, of purposefully satirical interventions into this discourse through various cultural activities from jokes to street art, political cartoons and beyond. Enormously successful films such as Four Lions or Team America: World Police, for instance, encourage us to laugh at established constructions of terrorists and counter-terrorists; inviting us to ridicule rather than fear, to see ineptitude rather than threat (Heath-Kelly and Jarvis 2017). Videogames, too, offer important critical potential in this context (see Robinson 2012, 2015; Young 2015; Schulzke 2017) once we move away from the mainstream 'military shooters' that dominate this genre. Thus, there are games which directly and often viscerally problematise militarism by forcing their players to navigate issues like Post-Traumatic Stress Disorder (PTSD). Others deliberately slow down the speed of play at particular moments in order to encourage more contemplative engagements with violence (Jarvis and Robinson forthcoming).

We can also, interestingly, see problematisations of this dominant discourse in diverse 'memory projects' engaging with (counter-)terrorist violences. Published obituaries of individuals such as Osama bin Laden - for instance - take us beyond simplistic condemnation of their subjects and their actions by humanising individuals through reflection on their character and their upbringing: 'Six feet three inches in height, Osama bin Laden was a handsome man. Visitors remarked on his beautiful manners and quiet speech, his accurate Arabic free of seminary affectation, his Hatim-like generosity with his inherited fortune, his hypochondria and good humour' (Buchan, 2011). Such obituaries also, frequently, contextualise campaigns of 'terrorist' violence by reference to structural contexts such as geopolitical backdrops, or the explicitly political ambitions of their authors. As this example, taken from a Guardian obituary of George Habash demonstrates, the outcome is a long way from widespread caricatures of terrorists as evil or religious zealots:

There was already an idealistic strain in his choice of careers: like many others, he was a doctor before he was a politician. It was his personal experience of the 1948 disaster which, more than anything else, fired in him a determination to devote himself to the politics of struggle (Hirst 2008).

We encounter dissenting, and sometimes explicitly critical, constructions, too, in less formal sites of social memory. The online archive Wherewereyou, for example, was set up as a repository for people to record their initial impressions of the 9/11 attacks (Jarvis 2011). While many of the 
contributions to this archive are congruent with official discourse at the time - reproducing the language of the Bush administration in the earliest framings of the 'war on terror', there are also important counter-examples in which this archive is used as an opportunity for critique. This occurs, in some instances, through the articulation and sharing of cosmopolitan arguments regarding the sanctity of all human life, for example: 'I hope the "people in charge" take heed to be extraordinarily careful in their actions. it will not fix the pain and sadness of all of the families that lost to make more families with losses on the other side of the globe' (WhereWereYouEntry \#118, cited in Jarvis 2011: 810). In other instances, it is through explicit efforts to re-imagine the American national identity in more complex, and perhaps precarious, ways than typically encountered in discussions of national security: 'let us not forget that most of us came from foreign families long ago. Save your anger for those involved in this act, not for their race and religion' (WhereWereYou Entry \#11, cited in Jarvis 2011: 810).

\section{Critical strategies}

My argument to this point has been that prominent understandings of terrorism as a particular and ubiquitous threat meriting sustained - perhaps exceptional - forms of response are actually more contested than one might think. This approach to terrorism - although widespread and welldocumented - is one which comes under scrutiny in a diverse range of spaces, from satirical films, to video games, memorial websites, everyday experiences, and even the language of political elites. Figure 4 provides an attempt to sketch some of the differences between these interventions, and to think through their implications and utility for critical terrorism studies, understood broadly. The figure should be approached, of course, as a heuristic; one characterised by imprecise and fluid boundaries, but also illustrative rather than exhaustive with examples taken from some of the research projects discussed above. ${ }^{\text {viii }}$

Figure 4: Terrorism, Counter-terrorism and Critique

\begin{tabular}{|l|l|l|l|}
\hline Strategy & Aims may include & Examples & Considerations \\
\hline Repudiate & $\begin{array}{l}\text { Rejection of basic } \\
\text { claims or } \\
\text { assumptions }\end{array}$ & $\begin{array}{l}\text { Media obituaries } \\
\text { 'State terrorism' } \\
\text { arguments }\end{array}$ & $\begin{array}{l}\text { Stability of alternative } \\
\text { truths? }\end{array}$ \\
\hline Question & $\begin{array}{l}\text { Elaboration } \\
\text { Justification }\end{array}$ & Parliamentary debate & $\begin{array}{l}\text { Constrained by dominant } \\
\text { discourses, and } \\
\text { established 'rules of the } \\
\text { game' }\end{array}$ \\
\hline Subvert & $\begin{array}{l}\text { Dissent } \\
\text { Ridicule }\end{array}$ & Political satire & $\begin{array}{l}\text { Possible marginalisation } \\
\text { Aesthetic impact }> \\
\text { political impact? }\end{array}$ \\
\hline
\end{tabular}




\begin{tabular}{|l|l|l|l|}
\hline Replace & Broadening & Citizen concerns & Questions of authority \\
& Diversifying & Vernacular memorials & Generalisability \\
\hline Deconstruct & Disturbance & $\begin{array}{l}\text { Contradictions in } \\
\text { political discourse } \\
\text { Destabilisation }\end{array}$ & Primarily disruptive? \\
& Deconstruction & & \\
\hline
\end{tabular}

Figure 4 identifies five distinctive critical strategies through which one might attempt to intervene in the contemporary politics of (counter-)terrorism. The first - and most obvious - of which is simply to reject the fundamental assumptions underpinning prominent assertions or constructions of these violences. Such a strategy - deliberate or otherwise - is present, I think, in some of the media obituaries considered above. Bin Laden, we saw, emerged in at least one example as a man situated in specific historical circumstances and possessing of redeeming characteristics: some distance, as such, from the personification of evil to which we have become accustomed. Arguments around 'state terrorism', too, do something similar in rejecting the artificial limiting of this term to non-state actors because so doing engenders inconsistent analysis or hypocritical policies. A critique of this sort, based upon a strategy of repudiation, is clearly seductive in the forthrightness with which constructions of terrorism are challenged. A risk, however, is that it contributes to a simple trading of truths about terrorism in a discursive contest that might never be settled. Why, for instance, would alternative understandings of terrorism (that might be capable of including state violences) or terrorists (as historically constituted) be any less susceptible to questioning or dissent than those one attempts to subvert or replace (see Jarvis 2009a)?

A second strategy is to ask the sorts of question we see in places like parliamentary debate (see Jarvis and Legrand 2017a), for instance: On what grounds has al Qaeda been identified as a terrorist group? Why are specific policy measures being introduced to counter the threat of terrorism now? And so on. This sort of strategy seems a useful one, to me, for eliciting explanation and justification from political elites, especially in the context of more draconian approaches to countering terrorism. It might also be less directly confrontational than outright repudiation, too, which may have strategic or political benefits in particular contexts. But critiques based on questioning also risk inhabiting a terrain that has already been established by those whom we might wish to question. What we are able to ask about, and when, where or how we frame and deliver those questions, is likely to be guided by existing conventions and rules that likely serve specific interests. This is certainly true in parliament. It is also true, I think, in other discursive contexts, from the pages of academic journals to seminar rooms, film studios, and beyond.

A third, perhaps more creative, approach involves attempting to subvert dominant ways of thinking about and responding to terrorism, for instance via satirical street art, films, and so forth. These efforts - as seen above - work to critique terrorist discourse through ridicule and derision, substituting fear or insecurity with laughter or mockery. Such forms of critique are typically creative, and often entertaining. But, because their aesthetic or cultural significance might be more overt than their political import, there is a risk here of marginalisation or shorttermism: a risk that interventions offered via such projects are delimited to the period of 
engagement then forgotten. On top of this, strategies of subversion based on laughter and the like should also not be seen as inherently progressive: as suggested elsewhere, racist, sexist, and homophobic caricatures of terrorists deploy similar resources to very different ends (Heath-Kelly and Jarvis 2017).

A fourth strategy is to replace dominant discourse in this area by bringing forward marginalised stories - or, indeed, helping to create such stories - through engagement with 'real people' in 'real communities' about their concerns or fears. Michel Foucault (1980: 81-82) discusses something similar in terms of re-activating or emancipating subjugated knowledges, and it is a strategy that has been put to productive use already within critical terrorism research and related scholarships (see Jackson 2012, 2015, 2018). Such a strategy facilitates a diversifying - and therefore broadening - of knowledge around (counter-)terrorism: telling dominant truths differently and engaging with the vernacular, the mundane, the everyday and the local (see Enloe 2011; Jarvis and Lister 2013b; Sylvester 2013; Vaughan-Williams and Sevens 2016). There are, to be clear, significant ethical questions that accompany efforts to speak on behalf of - or even to speak with - the marginal, the unqualified or the disposed in this way (Jarvis 2018); not least the extent to which 'vernacular' experiences or constructions constitute legitimate or appropriate research material. There are issues here, too, of generalisability, and the danger that such knowledge - and our interpretations thereof - can be dismissed as merely anecdotal.

A final, deconstructive, strategy involves not replacing nor even broadening conventional understandings of terrorism, but rather analysing how such understandings are themselves constructed. Such a strategy involves pulling attention to dominant representations of terrorism in language, film, and beyond, and to show these to be far more precarious - and far more open to change - than one might initially have thought. As indicated above, for instance, events such as the attacks of 11 September 2001 do not simply speak for themselves. Such events are given meaning in the way that we frame them (Jackson 2005). And, paying attention to those representations - to those frames - helps us expose their contradictions, their histories, their assumptions, and their implications for social, political and other forms of life. Such an approach must navigate longstanding accusations of triviality and conservatism (see Ashley and Walker 1990) - it might, for instance, have less to say about concrete alternatives to dominant terrorism discourses than some of the above strategies. But, disturbing rather than extending or replacing dominant conceptions of terrorism - and, indeed, other security challenges - can be a particularly productive way of making what seems inevitable, objective, or self-evident appear rather less so (e.g. Doty 1993; Campbell 1998; Jackson 2005; Hansen 2006; Holland 2013; Holland and Jarvis 2014).

\section{Conclusion}

Critical research around terrorism, counter-terrorism and related security challenges continues to progress from strength to strength. Recent collections (e.g. Stump and Dixit 2012; Miller et al 2013; Jackson 2018; Jackson et al 2018) demonstrate the diversity and vibrancy of contemporary work in this area, and the extent of conceptual and methodological innovation underpinning it. In this discussion I have attempted to draw on a number of my former research projects - as well as related scholarship - to reflect on the different forms of critical strategy available to those dissatisfied with dominant conceptions, assessments, and responses to 'terrorism'. Beyond demonstrating the extent to which such constructions are contested and critiqued across sociopolitical life, I hope to have sketched some of the assumptions, implications and challenges associated with specific types of intervention. This is not, of course, to argue that these are 
exhaustive - or even paradigmatic - of that which is available to critical terrorism studies. Rather to contribute to ongoing conversation about what the 'critical' might mean and imply in this and related research.

Each of the five strategies sketched above - repudiation, questioning, subversion, replacement, and deconstruction - has significant value, I think, for those who believe prominent ways of conceptualising and countering terrorism problematic. Frustratingly, perhaps, the success of any effort at critique is likely to be context-specific and only knowable in hindsight. Much of that success will depend on the capacities of critics, the resonance of the critiques they present, and the timeliness of critique vis-à-vis political opportunities, audience openness, and so on. My hope, however, is that the examples offered in this discussion provide some room for optimism and some pointers going forward as critical terrorism studies moves into and beyond its second decade.

\section{References}

Amoore, L., and M. De Goede. eds. 2008. Risk and the War on Terror. Abingdon: Routledge. Aradau, C., and Huysmans, J. 2014. "Critical methods in International Relations: The politics of techniques, devices and acts." European Journal of International Relations 20 (3): 596619.

Ashley, R. K., and R. B. J. Walker. 1990. "Conclusion: Reading dissidence/writing the discipline: Crisis and the question of sovereignty in international studies." International Studies Quarterly 34 (3): 367-416.

Baker-Beall, C., C. Heath-Kelly and L. Jarvis. eds. 2016. Counter-Radicalization: Critical Perspectives. Abingdon: Routledge.

Baker-Beall, C., C. Heath-Kelly and L. Jarvis. eds. 2018. Neoliberalism and/as Terror: Critical Engagements. Abingdon: Routledge.

BBC. 2013. "Nelson Mandela death: Tories 'right on South Africa", BBC Online, available online at: https://www.bbc.co.uk/news/uk-politics-25266180 accessed 3 December 2018.

BBC. 2016. "Old Trafford suspect device 'signed for' by security firm". available online via https://www.bbc.co.uk/sport/football/36306495, accessed 3 December 2018

Blakeley, R. 2007. "Bringing the State Back into Terrorism Studies." European Political Science 6 (3): 228-235.

Blakeley, R. 2009. State Terrorism and Neoliberalism: The North in the South. Abingdon: Routledge.

Browning, C. S. and M. McDonald. 2013. "The future of critical security studies: Ethics and the politics of security." European Journal of International Relations 19 (2): 235-255.

Buchan, J. 2011. "Osama bin Laden: Terrorist leader who waged jihad against 'Jews and Crusaders' and ordered the attacks of 11 September 2001." Independent Online, 3 May 2011, available via: https://www.independent.co.uk/news/obituaries/osama-bin-ladenterrorist-leader-who-waged-jihad-against-jews-and-crusaders-and-ordered-the-attacks2277996.html, accessed 14 December 2018.

Burnett, J. and D. Whyte. 2005. "Embedded Expertise and the New Terrorism." Journal for Crime, Conflict and the Media 1 (4): 1-18.

Campbell, D. 1998. Writing Security: United States Foreign Policy and the Politics of Identity. Minneapolis, MN: University of Minnesota Press. 
Carr, M. 2011. The Infernal Machine: An Alternative History of Terrorism. London: Hurst \& Company.

Chomsky, N. 2002. Pirates and Emperors, Old and New: International Terrorism in the Real World. London: Pluto Press.

Cohen, S. 2011. Folk Devils and Moral Panics. Abingdon: Routledge.

Crawford, N. 2017. "United States Budgetary Costs of Post-9/11 Wars Through FY2018: A Summary of the \$5.6 Trillion in Costs for the US Wars in Iraq, Syria, Afghanistan and Pakistan, and Post-9/11 Veterans Care and Homeland Security." November $\quad 2017$, available

https://watson.brown.edu/costsofwar/files/cow/imce/papers/2017/Costs $\% 20$ of $\% 20$ U.S. $\%$ 20Post-9 11\%20NC\%20Crawford\%20FINAL\%20.pdf accessed 17 December 2018.

Crawford, N. 2018a. "Human Cost of the Post-9/11 Wars: Lethality and the Need for Transparency." " November 2018, available via: https://watson.brown.edu/costsofwar/files/cow/imce/papers/2018/Human $\% 20$ Costs $\% 2 \mathrm{C}$ \%20Nov\%208\%202018\%20CoW.pdf accessed 17 December 2018.

Crawford, N. 2018b. "United States Budgetary Costs of the Post-9/11 Wars Through FY2019: \$5.9 Trillion Spent and Obligated." November 2018, available via: https://watson.brown.edu/costsofwar/files/cow/imce/papers/2018/Crawford_Costs\%20of \%20War\%20Estimates\%20Through\%20FY2019.pdf accessed 17 December 2018.

Croft, S. 2006. Culture, Crisis and America's War on Terror. Cambridge: Cambridge University Press.

De Simone, D. 2018. "National Action: The new parents and the neo-Nazi terror threat." $B B C$ News Online, 12 November 2018, available via: https://www.bbc.co.uk/news/stories45919730 accessed 17 December 2018.

Dexter, H. 2012. "Terrorism and violence: another violence is possible?" Critical Studies on Terrorism 5 (1): 121-137.

Dodd, T. 2016. "Anjem Choudary jailed for five-and-a-half years for urging support of Isis." Guardian, 6 September 2016, available via: https://www.theguardian.com/uknews/2016/sep/06/anjem-choudary-jailed-for-five-years-and-six-months-for-urgingsupport-of-isis accessed 17 December 2018.

Doty, R. L. 1993. "Foreign policy as social construction: A post-positivist analysis of US counterinsurgency policy in the Philippines." International Studies Quarterly 37 (3): 297320.

Enloe, C. 2011. “The mundane matters.” International Political Sociology 5 (4): 447-450.

Fitzgerald, J. 2015. "Why me? An autoethnographic account of the bizarre logic of counterterrorism." Critical Studies on Terrorism 8 (1): 163-180.

Forcese, C. and K. Roach. 2018. "Yesterday's Law: Terrorist Group Listing in Canada." Terrorism and Political Violence 30 (2): 259-277.

Foucault, M. 1980. Power/Knowledge: Selected Interviews and Other Writings 1972-1977 by Michel Foucault, Edited by Colin Gordon. London: Longman.

George, A., ed. 1991. Western State Terrorism. Cambridge: Polity Press.

GTD. n.d. "Data Collection Methodology." available online via: https://www.start.umd.edu/gtd/using-gtd/ accessed 3 December 2018.

Guardian. 2015. "Professor: flight was delayed because my equations raised terror fears." Guardian, available online via: https://www.theguardian.com/us- 
news/2016/may/07/professor-flight-delay-terrorism-equation-american-airlines accessed 3 December 2018.

Gunning, J. 2007. “A Case for Critical Terrorism Studies?” Government and Opposition 42 (3): 363-393.

Gunning, J. and R. Jackson. 2011. "What's so 'religious' about 'religious terrorism'?" Critical Studies on Terrorism 4 (3): 369-388.

Hansen, L. 2006. Security as Practice: Discourse Analysis and the Bosnian War. Abingdon: Routledge.

Heath-Kelly, C. and E. Strausz (forthcoming) "The banality of counterterrorism "after, after 9/11"? Perspectives on the Prevent duty from the UK health care sector." Critical Studies on Terrorism. Available online first at: https://www.tandfonline.com/doi/full/10.1080/17539153.2018.1494123

Heath-Kelly, C. and L. Jarvis. 2017. "Affecting Terrorism: Laughter, Lamentation, and Detestation as Drives to Terrorism Knowledge." International Political Sociology 11(3): 239-256.

Hirst, G. 2008. "George Habash." The Guardian, 27 January 2008, available via: https://www.theguardian.com/world/2008/jan/27/israelandthepalestinians.obituaries, accessed 14 December 2018.

Holland, J. 2011. "'When You Think of the Taliban, Think of the Nazis': Teaching Americans '9/11' in NBC's The West Wing." Millennium: Journal of International Studies 40 (1): 85-106.

Holland, J. 2013. "Foreign policy and political possibility." European Journal of International Relations 19 (1): 49-68.

Holland, J. and L. Jarvis. 2014. ““Night fell on a different world”: experiencing, constructing and remembering 9/11." Critical Studies on Terrorism 7 (2): 187-204.

Home Office. 2017. Proscribed Terrorist Groups or Organisations. Available online via https://assets.publishing.service.gov.uk/government/uploads/system/uploads/attachment data/file/670599/20171222 Proscription.pdf, accessed 10 December 2018.

Hughes, M. and J. Walsh. 2010. "Twitter joke led to Terror Act arrest and airport life ban." Independent, available online via: https://www.independent.co.uk/news/uk/homenews/twitter-joke-led-to-terror-act-arrest-and-airport-life-ban-1870913.html accessed 3 December 2018.

Hulsse, R., and A. Spencer. 2008. "The Metaphor of Terror: Terrorism Studies and the Constructivist Turn." Security Dialogue 39 (6): 571-592.

Iraq Body Count (n.d.) "Iraq Body Count." available via: https://www.iraqbodycount.org/ accessed 17 December 2018.

Jackson, R. 2005. Writing the War on Terrorism: Language, Politics and Counter-Terrorism. Manchester: Manchester University Press.

Jackson, R. 2008. "The Ghosts of State Terror: Knowledge, Politics and Terrorism Studies." Critical Studies on Terrorism 1 (3): 377-392.

Jackson, R. 2009. "Knowledge, power and politics in the study of political terrorism." In Critical Terrorism Studies: A New Research Agenda, edited by R. Jackson, M. Breen Smyth and J. Gunning, 66-83. Abingdon: Routledge.

Jackson, R. 2012. "Unknown knowns: The subjugated knowledge of terrorism studies." Critical Studies on Terrorism 5 (1): 11-29. 
Jackson, R. 2015. "The epistemological crisis of counterterrorism." Critical Studies on Terrorism 8 (1): 33-54.

Jackson, R. 2018. "Pacifism: the anatomy of a subjugated knowledge." Critical Studies on Security 6 (2): 160-175.

Jackson, R. ed. 2018. Routledge Handbook of Critical Terrorism Studies. Abingdon: Routledge. Jackson, R. and Hall, G. 2016. "Talking about terrorism: A study of vernacular discourse." Politics 36 (3): 292-307.

Jackson, R., E. Murphy, and S. Poynting. 2010. "Introduction: Terrorism, the State and the Study of Political Terror." In Contemporary State Terrorism: Theory and Practice, edited by R. Jackson, E. Murphy, and S. Poynting, 1-11. Abingdon: Routledge.

Jackson, R., E. Murphy, and S. Poynting. eds. 2010. Contemporary State Terrorism: Theory and Practice. Abingdon: Routledge.

Jackson, R., L. Jarvis, J. Gunning, and M. Breen Smyth. 2011. Terrorism: A Critical Introduction. Basingstoke: Palgrave.

Jackson, R., M. Breen Smyth, and J. Gunning. 2009. "Critical Terrorism Studies: Framing a new Research Agenda". In Critical Terrorism Studies: A New Research Agenda, edited by R. Jackson, M. Breen Smyth and J. Gunning, 216-236. Abingdon: Routledge.

Jackson, R., H. Toros, L. Jarvis and C. Heath-Kelly. 2018. Critical Terrorism Studies at Ten: Contributions, Cases and Future Challenges. Abingdon: Routledge.

Jarvis, L. 2009a. "The Spaces and Faces of Critical Terrorism Studies." Security Dialogue 40 (1): 5-27.

Jarvis, L. 2009b. Times of Terror: Discourse, Temporality and the War on Terror. Basingstoke: Palgrave.

Jarvis, L. 2011. "9/11 Digitally Remastered? Internet Archives, Vernacular Memories and WhereWereYou.org." Journal of American Studies 45 (4): 793-814.

Jarvis, L. 2018. "Toward a Vernacular Security Studies: Origins, Interlocutors, Contributions, and Challenges." International Studies Review, available online first via doi: https://doi.org/10.1093/isr/viy017

Jarvis, L. and T. Legrand. 2016. "Legislating for Otherness: Proscription powers and parliamentary discourse." Review of International Studies 42 (3): 558-574.

Jarvis, L. and T. Legrand. 2017a. "II am somewhat puzzled': Questions, audiences and securitization in the proscription of terrorist organizations." Security Dialogue 48 (2): 149167.

Jarvis, L. and T. Legrand. 2017b. "Preaching to the Converted: Parliament and the Proscription Ritual." Political Studies 65 (4): 947-965.

Jarvis, L. and T. Legrand. 2018. "The Proscription or Listing of Terrorist Organisations: Understanding, Assessment, and International Comparisons." Terrorism and Political Violence 30 (2): 199-215.

Jarvis, L. and M. Lister. 2013a. "Disconnected Citizenship? The Impacts of Anti-Terrorism Policy on Citizenship in the UK." Political Studies 61 (3): 656-675.

Jarvis, L. and M. Lister. 2013b. 'Vernacular Securities and Their Study: A Qualitative Analysis and Research Agenda', International Relations 27 (2): 158-179.

Jarvis, L. and M. Lister. 2014. "State terrorism research and critical terrorism studies: an assessment." Critical Studies on Terrorism 7 (1): 43-61.

Jarvis, L. and M. Lister. 2015. Anti-Terrorism, Citizenship and Security. Manchester: Manchester University Press. 
Jarvis, L. and M. Lister. 2017a. “'As a woman...'; 'As a Muslim...': Subjects, positions and counter-terrorism powers in the United Kingdom.” Critical Social Policy 37 (2): 245-267.

Jarvis, L. and M. Lister. 2017b. "What would you do? Everyday conceptions and constructions of counter-terrorism." Politics 36 (3): 277-291.

Jarvis, L. and N. Robinson. (forthcoming) "War, Time and Military Videogames: Heterogeneities and Critical Potential." Submitted for publication.

Jarvis, L., S. Macdonald and A. Whiting. 2016. "Analogy and Authority in Cyberterrorism Discourse: An Analysis of Global News Media Coverage." Global Society 30 (4): 605623.

Legrand, T. 2018. “"More Symbolic-More Political-Than Substantive”: An Interview with James R. Clapper on the U.S. Designation of Foreign Terrorist Organizations." Terrorism and Political Violence 30 (2): 356-372.

McDonald, M. 2009. "Emancipation and critical terrorism studies.". In Critical Terrorism Studies: A New Research Agenda. Edited by R. Jackson, M. Breen Smyth and J. Gunning, 109-123. Abingdon: Routledge.

McGarrity, N. and G. Williams. 2018. "The Proscription of Terrorist Organisations in Australia." Terrorism and Political Violence 30 (2): 216-235.

Michaels, S. 2014. "Madonna new music leak is 'form of terrorism' says singer." The Guardian, 18 December 2014, available online at: https://www.theguardian.com/music/2014/dec/18/madonna-new-music-leak-terrorismiconic accessed 3 December 2018.

Miller, D., J. Blackbourn, R. Dhanda and H. Dexter. eds. 2013. Critical Terrorism Studies Since 9/11: What has been Learned? Abingdon: Routledge.

Morgan, M. ed. 2009. The Impact of 9/11 on the Media, Arts and Entertainment: The Day that Changed Everything? Basingstoke: Palgrave.

Morgan, M. J. 2004. "The Garrison State Revisited: Civil-military Implications of Terrorism and Security." Contemporary Politics 10 (1): 5-19.

Mueller, J. 2009. Overblown: How Politicians and the Terrorism Industry Inflate National Security Threats, and Why We Believe Them. New York, NY: Simon and Schuster.

Neal, A. W. 2009. Exceptionalism and the Politics of Counter-Terrorism Liberty, Security and the War on Terror. Abingdon: Routledge.

Nobel Media. n.d. "Nelson Mandela - Facts. NobelPrize.org." available online at: https://www.nobelprize.org/prizes/peace/1993/mandela/facts/ accessed 3 December 2018.

Pantazis, C., \& S. Pemberton. 2009. "From the 'Old' to the 'New' Suspect Community: Examining the Impacts of Recent UK Counter-Terrorist Legislation.” The British Journal of Criminology 49 (5): 646-666.

Pears, L. 2016. "Ask the audience: television, security and Homeland." Critical Studies on Terrorism 9 (1): 76-96.

Petridis, A. 2014. 'Madonna: I did not say, 'Hey, here's my music, and it's finished.' It was theft." The Guardian, 21 December 2014, available online at: https://www.theguardian.com/music/2014/dec/21/madonna-album-hack-living-stateterror accessed 3 December 2018.

Powell, J. 2015. Talking to Terrorists: How to End Armed Conflicts. London: Vintage.

Pullella, P. 2007. "Vatican says gay marriage evil and abortion terrorism." Reuters, 23 April 2007, available online at: https://www.reuters.com/article/uk-pope-gays/vatican-says-gay- 
marriage-evil-and-abortion-terrorism-idUKL2336409320070423 accessed 3 December 2018 .

Robinson, N. 2012. "Videogames, Persuasion and the War on Terror: Escaping or Embedding the Military-Entertainment Complex?" Political Studies 60 (3): 504-22.

Robinson, N. 2015. "Have You Won the War on Terror? Military Videogames and the State of American Exceptionalism." Millennium: Journal of International Studies 43 (2): 450-470.

Roe, P. 2004. "Securitization and Minority Rights: Conditions of Desecuritization." Security Dialogue 35 (3): 279-294.

Sabir, R. 2011. "I won terror compensation, but my struggle for justice continues." Guardian, available online via: https://www.theguardian.com/commentisfree/2011/sep/19/terrorcompensation-police-university accessed 3 December 2018.

Schmid, A. 2013. "The Definition of Terrorism." The Routledge Handbook of Terrorism Research, edited by A. Schmid, 39-98. Abingdon: Routledge.

Schulzke, M. 2017. "Interpreting and Reinterpreting the Political Significance of Popular Media: The Importance of Seeing from a Range of Perspectives." Political Studies 65 (4): 930-46.

Shanahan, T. 2010. "Betraying a certain corruption of mind: how (and how not) to define 'terrorism'." Critical Studies on Terrorism 3 (2): 173:190.

Stevens, D. and N. Vaughan-Williams. 2017. Everyday Security Threats: Perceptions, Experiences and Consequences. Manchester: Manchester University Press.

Stohl, M., and G. Lopez. eds. 1984. The State as Terrorist: The Dynamics of Governmental Violence and Repression. Westport, CT: Greenwood Press.

Stohl, M. and G. Lopez. eds. 1988. Terrible Beyond Endurance? The Foreign Policy of State Terrorism, Westport, CT: Greenwood Press.

Stump, J. L. and P. Dixit. 2012. Critical Terrorism Studies: An Introduction to Research Methods. Abingdon: Routledge.

Sylvester, C. 2013. "Experiencing the end and afterlives of International Relations/theory." European Journal of International Relations 19 (3): 609-626.

Toros, H. 2008. “'We Don't Negotiate with Terrorists!': Legitimacy and Complexity in Terrorist Conflicts." Security Dialogue 39 (4): 407-426.

Toros, H. and J. Gunning. 2009. "Exploring a critical theory approach to terrorism studies." In Critical Terrorism Studies: A New Research Agenda, edited by R. Jackson, M. Breen Smyth and J. Gunnin, 87-108. Abingdon: Routledge.

Vaughan-Williams, N., \& D. Stevens. 2016. "Vernacular theories of everyday (in) security: The disruptive potential of non-elite knowledge." Security Dialogue 47 (1): 40-58.

Victor, D. 2016. "Ahmed Mohamed, Boy Handcuffed for Making Clock, Is Suing." The New York Times, available online via: https:/www.nytimes.com/2016/08/09/us/ahmedmohamed-boy-handcuffed-for-making-clock-is-suing.html accessed 3 December 2018, accessed 3 December 2018.

Walker, C. 2018. ““They haven't gone away you know.” The Persistence of Proscription and the Problems of Deproscription." Terrorism and Political Violence 30 (2): 236-258.

Young, R. 2015. "Going Fifth Freedom: Fighting the War on Terror in the Splinter Cell: Blacklist Video Game." Critical Studies on Terrorism 8 (1): 147-62.

Zulaika, J. and W. Douglass. 1996. Terror and Taboo: The Follies, Fables and Faces of Terrorism. Abingdon: Routledge. 


\footnotetext{
i Email: 1.jarvis@uea.ac.uk

ii My thanks goes to everyone who attended the inaugural lecture, and to all those who have contributed to the work upon which I here draw. This includes the very many co-authors and co-editors with whom I have worked over the years and whose ideas undoubtedly run through this discussion, as well as many other colleagues and friends for their time, insight and, indeed, critique. My thanks, too, to Richard Jackson for his encouragement in publishing this revised version of the lecture in Critical Studies on Terrorism. The full lecture may be watched here https://www.youtube.com/watch? v=Ec4eekn-TAY\&index=2\&list=PL0szx1BNfw916AFcn8vkPcnRAPb3v7KT_ and any errors, of course, remain my own.

iii Such security exercises and action, at times, can very directly produce their own insecurities as with an incident at Old Trafford football ground in 2016. On this occasion, a fake device unwittingly left behind after a security training event was subsequently discovered by a member of the public and interpreted as a real threat, leading to the ground's evacuation twenty minutes before a Manchester United football match kicked off (BBC 2016).

${ }^{\text {iv }}$ Because this discussion comes out of an inaugural lecture, the examples given below draw primarily on my own previous research projects.

${ }^{v}$ Adapted from Jarvis (2009b)

vi Adapted from Jarvis and Lister (2013a)

vii Further information on the project can be found via: https://britishmuslimvalues.wordpress.com/about/

viii Important discussions of critique and criticism that have influenced my thinking and the discussion in this section include Ashley and Walker 1990; Roe 2004; Browning and McDonald 2013; Aradau and Huysmans 2014.
} 